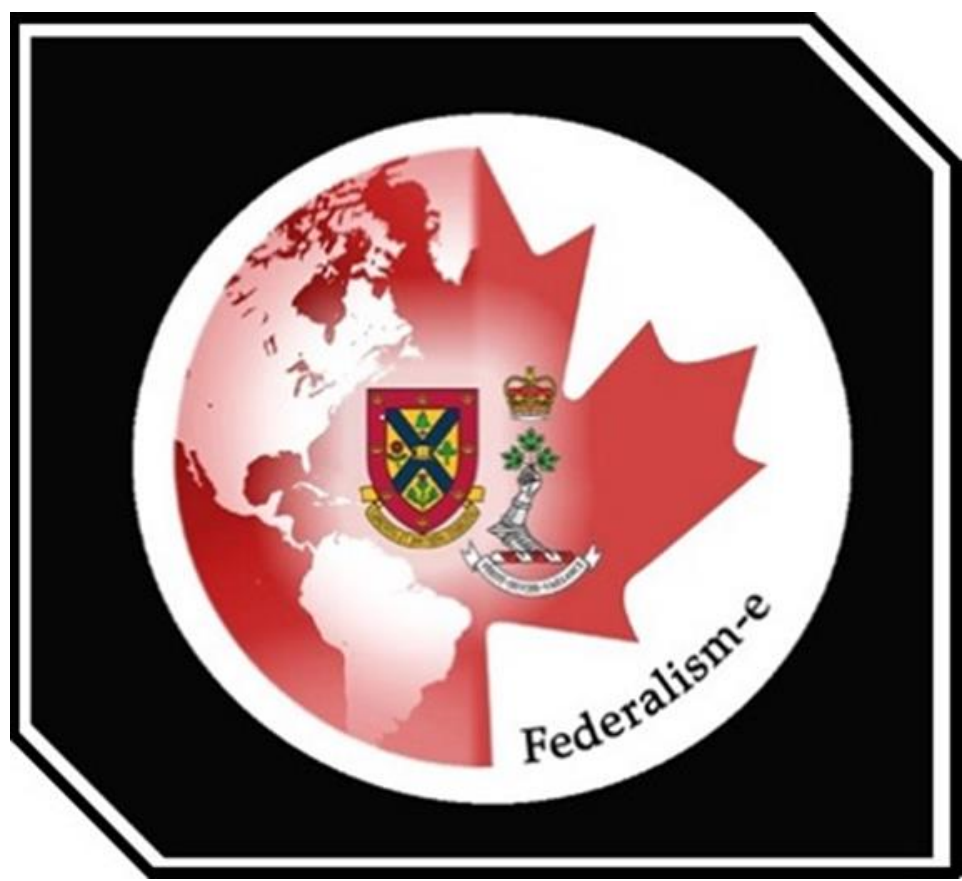

\title{
Federalism-E
}

\section{Phases of Canadian Federalism}

\author{
By: OCdt Michelle Evans
}

Royal Military College of Canada

Federalism-E is founded by the Royal Military College of Canada and the Institute of Intergovernmental Relations at Queen's University

Federalism-E Vol. 20, No.1 (2019) 
Federalism- $E$ is an online, undergraduate student-run journal focusing on the theory of federalism. Federalism-E publishes academic articles and essays focusing on federalism, multi-level governance, and intergovernmental relations. Publishing in both English and French, the journal has a mandate to provide a forum encouraging research and scholarly debate with respect to a wide variety of issues concerning federalism, both within Canada and abroad.

\section{Editors-in-Chief}

Officer Cadet Miles Smith, Royal Military College of Canada

Officer Cadet Alexandre Veilleux, Royal Military College of Canada

\section{Associate Editors:}

Officer Cadet Jack Wery, Royal Military College of Canada

Officer Cadet Jack Murphy, Royal Military College of Canada

Officer Cadet Damian McCracken, Royal Military College of Canada

Rylee Rose Kloek, University of Ottawa

Joyce Le-Yi Yang, University of Toronto

Mduduzi Mhlanga, University of Toronto

Srijan Sahu, University of Toronto

Jenna Mohammed, University of Toronto Mississauga

Ali Bachir Taha, University of Toronto

Charmaine Lee, University of British Columbia

\section{Faculty Advisor:}

Dr. Christian Leuprecht, Royal Military College of Canada, Institute of Intergovernmental Relations at Queen's University

\section{Contact Information:}

Address: Royal Military College of Canada

13 General Crerar Crescent

Kingston

ON, K7K 7B4

ISSN: 2562-3435

Email: federalismeditors@gmail.com

Website: https://ojs.library.queensu.ca/index.php/fede

Federalism-E is founded by the Royal Military College of Canada and the Institute of Intergovernmental Relations at Queen's University

Federalism-E Vol. 20, No.1 (2019) 
It is impossible to discuss Canadian federalism without considering the historical factors that have informed the evolution of the institution itself. Simeon and Robinson evaluate the evolutionary path of Canadian federalism throughout history using the lens of historical institutionalism. In Simeon and Robinson's “The Dynamics of Canadian Federalism” in James Bickerton and Alain-G. Gagnon's Canadian Politics 5th ed., the authors argue that the best way to understand Canadian federalism is by evaluating how key historical factors shaped the application of federal principles. They categorize Canadian federalism into periods and outline which historical factors defined the type of federalism that was pertinent at the time. Canadian federalism has achieved great success in responding to both internal and international political crises through strong leadership and maintaining the federation despite historical pressures. The question remains, what factors of Canadian politics will inform the next phase of Canadian federalism?

The first period of colonial federalism prevailed in Canadian society after 1867. During this turbulent time, the new Dominion of Canada was faced with three main concerns. The first was political in nature and had to do with addressing the linguistic tension that would be inherent to a bilingual society. Secondly, Britain was no longer favouring colonial exports that had previously given an advantage to Canadian goods abroad, causing an economic crisis. The final concern was defence based and stemmed from the fear of an attack from the South (Simeon and Robinson 2009, 107). According to Simeon and Robinson, these three considerations were key to informing the first phase of Canadian federalism. The federation was, at first, largely centralized. MacDonald saw the federal government as the colonial parent that would oversee all affairs and did not hesitate to utilize the powers of reservation and disallowance. This form of governing was not popular with the provinces and pressure was put on the central government to decentralize. Simeon and Robinson highlight the aggressive use of federal power by MacDonald and demonstrate the impact of this policy in alienating Quebec residents and francophones outside of Quebec. MacDonald is criticized with failing to protect the minority groups from repeated attacks on French language from provincial legislation (Simeon and Robinson 2009, 109).

The article argues that the next key period of Canadian history was defined by classical federalism. Following the conclusion of the First World War, the provinces took greater control of their own affairs and reduced their dependence on federal subsidies (Simeon and Robinson 2009, 109). This independence, however, was short lived. The onset of the Great Depression brought on a variety of federal relief programs. The Rowell-Sirois Commission recommended numerous reforms to the federal system. It put pressure on the federal system to redistribute financial resources. This commission is still referenced for the profound impact it had on shaping the anglophone view of Canadian federalism. Francophone publications identify the Tremblay Commission as a paramount document that informs the view of many Quebec francophones. The Tremblay Commission calls for a federation that has two orders of equal and co-ordinated governments (Rocher 2009, 99). French speaking Canadians were staunchly opposed to accepting the federal government's superiority. Numerous provinces continued to resist federal interference, but this resistance was set aside during the Second World War.

The post-war period realized four distinct phases of Canadian federalism. Cooperative federalism lasted until the early 1960s. Competitive federalism defined the debate until the 1980s 
when constitutional federalism took over. Finally, collaborative federalism asserted its dominance when the following decade arrived. The period of cooperative federalism allowed Ottawa to develop a basic income security system and a variety of other federal programs that were outlined in the Green Book Proposals of 1945. Competitive federalism was triggered by the election of Jean Lesage and the Quiet Revolution in Quebec (Simeon and Robinson 2009, 109). The Quebec Pension Plan is only one example of Quebec's attempts to resist federal intervention. Prime Minister Trudeau countered Quebec and fought for a bilingual and bicultural Canada into the next phase of Canadian federalism defined as Constitutional federalism.

Constitutional federalism is not solely defined by the repatriation of the Constitution in 1982 that bestowed upon Canada an amending formula and a Charter of Rights and Freedoms. It also considers Meech Lake, Charlottetown, and the Tripe-E Senate debates that demonstrated how challenging it would be to accommodate for the individual preferences of every group in the country (Simeon and Robinson 2009, 109). Repeated attempts at constitutional federalism failed and politicians turned their focus to making the "federation work better" through "nonconstitutional renewal" (Simeon and Robinson 2009, 109).

This period became known as a time of collaborative federalism where the provinces and the federal government worked together to adapt and modernize the federation so that it could address social and economic issues (Simeon and Robinson 2009, 121). Other experts on Canadian federalism agree that the 1990s were a period of relative stability where federal and provincial legislatures were afforded room to legislate (Aronovitch 2005, 317). This was the final period that Simeon and Robinson deemed to be significant enough to categorize into its own section. Following this period, Simeon and Robinson look to the future of Canadian federalism and draw conclusions. Donald Smiley's concept of executive federalism is referenced as it highlights how contemporary Canadian federalism promotes negotiation among officials and ministers of the federal and provincial governments conciliate and agree upon a system of sharing responsibilities (Simeon and Robinson 2009, 118). They consider what future problems might face Canadian federalism. These concerns include, shifting intergovernmental discussion so that it is more open and transparent to citizens, holding policy debates to a higher standard regarding substance issues and balancing national standards, letting local government defend local interests, and finally, considering multilevel layers of federalism beyond federal and provincial to include indigenous and municipal (Simeon and Robinson 2009, 122).

Simeon and Robinson argue that these historical periods define Canadian federalism and are key to understanding the evolutionary path that the federal system has undergone. The authors arguably downplayed the influence that the United States has indubitably played in the evolution of Canadian federalism. Beyond the threat of a United States invasion at the time of Confederation and the New Deal offered during the Great Depression, there is no mention of the role the United States had in shaping Canadian politics. Additionally, Indigenous relations are not discussed until Meech Lake. There is no concern given to how indigenous peoples were affected by each historical phase despite myriad protests from the Indigenous community throughout history at the loss of their self-governance. Indigenous groups, like the Métis, reference the Royal Proclamation of 1763 which suggests that Canadian federalism is founded on the co-existence of self-governing nations. (Dubois and Saunders 2013, 187). For centuries, Indigenous peoples have argued that they are entitled to recognition by the state as a unique 
entity in the political and institutional landscape of the country. Simeon and Robinson conclude that the future of Canadian federalism will have to address indigenous governance. How will the next phase of Canadian federalism address the cleavages in Canadian society?

As alluded to by Simeon and Robinson, the future of Canadian federalism must account for the presence of Indigenous people, but how is this task achievable when their voice is often lost in a First-Past-the-Post system? Electoral reform has been broached on numerous occasions, but with little success. As Canada strives to build a more inclusive state it has become increasingly difficult to ignore the clear advantage that a shift to a mixed-member-proportional system would provide. This transition would enable greater representation for Indigenous people and visible minorities.Minority groups could elect a representative of their own to voice their interests in government. However, the Canadian population is hesitant to transition away from their political tradition. Canadian federalism is overly invested in a First-Past-the-Post system, and consequently, it has become part of Canada's political culture as a symbol of its connection to the British. Some theorists argue that First-Past-the-Post was never the most appropriate system for Canada and it has actually increased the challenges associated with managing Canada's many regional, ethnic, and linguistic divisions (Leduc 2009, 21). Indigenous people are considering innovative governance structures and ways to achieve economic self-sufficiency so that they too can challenge the federal government to address an often forgotten distinct society that has been overlooked in Canadian federalism. Despite Canada's federalist tradition of operating under the arc of a First-Past-the-Post system, the benefits of adopting features of a proportional representation should inform the next phase of Canadian federalism. The history of Canadian federalism has been informed by its ability to respond to key historical events. However, the future should encompass Canada's commitment to representing its citizens in the most effective manner. 


\section{Bibliography}

Aronovitch, Hilliard. "Trudeau or Taylor? The Central Question." Critical Review of International Social and Political Philosophy 8, no. 3 (2005): 309-25. doi: 10.1080/13698230500187185.

Dubois, Janique, and Kelly Saunders. "“Just Do It!": Carving Out a Space for the Métis in Canadian Federalism." Canadian Journal of Political Science/Revue Canadienne De Science Politique 46, no. 1 (March 2013): 187-214. doi:https://doi.org/10.1017/S0008423913000164.

Gagnon, Alain C., Francois Rocher. The Quebec-Canada Dynamic or the Negation of the Ideal of Federalism. Toronto: University of Toronto Press, 2009.

Gagnon, Alain G., Richard Simeon, James Bickerton, and Ian Robinson. Canadian Politics 5th $E d .$, .

Leduc, Lawrence. "The Failure of Electoral Reform Proposals in Canada." Political Science 61, no. 2 (2009): 21-40. doi:10.1177/00323187090610020301. 